Article

\title{
Do We Need Reasons for the Normativity of Belief?
}

Marco A. Joven-Romero

\begin{abstract}
Here, I defend a constitutive normative account of belief regardless of reasons for belief emergence and based on the believer's attitude. I first sketch the dichotomy between evidential and nonevidential reasons to believe. Then I relate this dichotomy to doxastic and pragmatic approaches on the nature and the aim of belief. Then I analyze Daniel Whiting's approach, based on evidentialism, that accommodates pragmatic and epistemic aims of belief and the related further actions and thoughts. I finally defend a doxastic characterization of belief that relies on the attitude of the believer while believing: a person $x$ believes $p$ if and only if $x$ considers $p$ to be true.
\end{abstract}

Keywords: evidentialism, doxastic absolutism, pragmatism, wishful thinking

\section{Introduction}

$\mathrm{N}$

ormativist epistemologists usually argue that the doxastic norm of belief relies on the fact that agents take evidence as the only reason to believe. ${ }^{1}$ Pragmatists usually argue that nonevidential facts, like the motivational ones, may come into play when developing beliefs. ${ }^{2}$ There may be a tension between cognitive and possible conative facts that encourage belief formation. In that way, pragmatists state that there is not any fixed constitutive doxastic rule for beliefs. Beliefs may present good or bad outcomes, but that is an evaluative question in terms of different standards of correctness.

${ }^{1}$ See the following: Pascal Engel, "Belief and the Right Kind of Reason," in Teorema: Revista Internacional de Filosofía, 32:3 (2013), 19-34 and Pascal Engel, "In Defense of Normativism About the Aim of Belief," in The Aim of Belief, ed. by Timothy Chan (Oxford: Oxford University Press, 2013), 43-85.

2 See Susanna Rinard, "Against the New Evidentialists," in Philosophical Issues, 25:1 (2015), 208-23.

(c) 2018 Marco A. Joven-Romero

https://www.kritike.org/journal/issue 22/joven-romero june2018.pdf

ISSN 1908-7330

$(c c)$ BY-NC-ND 
I defend a constitutive norm of belief based on believers' attitudes: an agent $S$ that believes $p$, takes $p$ to be true. The belief $p$ may be true or false, and other evaluative norms of belief can evaluate the belief and the believer in terms of epistemic and nonepistemic standards of correctness. ${ }^{3}$ The constitutive norm I consider can accommodate to cases in which the evidence to believe is poor or there seems to be nonevidential reasons to believe. In that way, I defend a constitutive relation between belief and truth even if reasons to believe are based on poor or no evidence. Moreover, I defend, in general, a constitutive link between belief and truth independently of the reasons for belief.

In the first part of this paper, I briefly sketch the epistemic dichotomy between evidential and nonevidential reasons to believe. I show how the evidentialist positions are related to doxastic positions-i.e., how the aim and the norm of truth usually relate to a commitment to evidence-and how the nonevidentialist position relates to non-doxastic positions-i.e., how the aim of 'the practical' is sometimes related to nonevidential reasons to belief, like the motivational ones.

Second, I introduce the different approaches to the aim of belief. I sketch the normative and the nonnormative accounts and I develop the norm I am considering.

Third, I analyze the suggesting approach given by Daniel Whiting, ${ }^{4}$ who considers a practical aim of belief that relies in the evidence the agents take in order to develop beliefs, i.e., beliefs are based on evidence, beliefs aim at truth, and in that way, beliefs promote further practical actions. In that way, he tries to accommodate practical outcomes and truth.

I finally show the problems these approaches face and I state that the normativity of belief relies in the believers' taking their beliefs to be true, no matter if beliefs are developed with an evidential or a nonevidential basis. The truth and the falsity of beliefs connote an evaluative question that is not mandatory to establish a relation between belief and truth. Although beliefs can be correct or incorrect if they turn out to be true or false, respectively, the constitutive normativity of belief relies on the believer's commitment to truth regardless of the final result.

Here I refer to three different kinds of cases: (1) beliefs based on reliable evidence that aim at truth and in which the truth is practical; (2)

\footnotetext{
${ }^{3}$ See the following: Engel, "Belief and the Right Kind of Reason."; Engel, "In Defense of Normativism About the Aim of Belief."; Daniel Whiting, "Should I Believe the Truth?" in Dialectica, 64:2 (2010), 213-24; Timothy Williamson, Knowledge and its Limits (Oxford: Oxford University Press, 2000); John Gibbons, "Knowledge versus Truth," in Epistemic Norms: New Essays on Action, Belief, and Assertion, ed. by Clayton Littlejohn and John Turri (Oxford: Oxford University Press, 2014), 97-114.

${ }^{4}$ See Daniel Whiting, "Reasons for Belief, Reasons for Action, the Aim of Belief, and the Aim of Action," in Epistemic Norms: New Essays on Action, Belief, and Assertion, 219-37.
}

(C) 2018 Marco A. Joven-Romero https://www.kritike.org/journal/issue 22/joven-romero june2018.pdf 
beliefs based on poor (or no) evidence that are false but practical, at least in the short run; and (3) beliefs based on reliable evidence that aim at truth but are not practical.

It should be noted that I make a difference between the evidential and the nonevidential in terms of epistemic and nonepistemic reasons. I do not want to use the term 'practical reasons' in contrast to 'epistemic reasons,' as sometimes the epistemic is the practical, and other times the nonepistemic is likely to be more practical. ${ }^{5}$ The practical is not at odds with the epistemic nor the nonepistemic.

\section{Evidential Reasons vs. Nonevidential Reasons}

(Hugo's pig case) Hugo sees something. It has a pig tail. It has pig ears. It smells like a pig. It snores like a pig. Hugo believes that he sees a pig.

Evidentialism considers that evidence is the reason for belief. The agents create beliefs because they receive evidential inputs. Hugo believes he sees a pig because he has straight evidence to believe so. Nevertheless, some beliefs are developed out of straight evidential inputs:

(Tom's teacher case) Tom is in class. His teacher tells him and the rest of the pupils that the Earth is not the center of the universe. So, he believes that the Earth is not the center of the universe.

In this case, Tom and the pupils do not have any perceptual evidence to create their beliefs. But, as they trust their teacher, Tom and the pupils finally believe what the teacher says. Although there is no direct perceptual evidence, evidentialist philosophers may establish that Tom and the pupils have enough evidence to develop their beliefs.

Agents deal with different kinds of evidence: the one given by perceptual inputs, the one given by expertise and trustworthiness, the one given by social conditioning, and the one given by previous personal experiences. But even admitting a broader scope of evidence, the evidentialist has to deal with other complex cases, like wishful thinking ones:

(Mark's love case) Mark is in love with Andrea and he is convinced that it is a requited love. Andrea does not love Mark, and she tells him so. Furthermore, Mark's friends

${ }^{5}$ See Rinard, "Against the New Evidentialists."

(C) 2018 Marco A. Joven-Romero

https://www.kritike.org/journal/issue 22/joven-romero june2018.pdf

ISSN 1908-7330

(c) BY-NC-ND 
try to convince him showing opposite evidence and Mark has seen Andrea dating another boy many times. But it does not matter: for Mark, Andrea is just playing hardball with him. Mark believes Andrea loves him too.

The evidentialist has several options. She can say that Mark's state is not belief, but just something like 'stubborn conviction' or schmelief,' a state similar to belief but "governed by other aims, such as comfort and pleasantness." 7 But to consider that Mark's state is not a belief is a revisionist, nonplausible option: most people agree that Mark's state is a belief, even being a false one. A more plausible way of dealing with these kinds of cases from an evidentialist approach is to consider that Mark has many available pieces of evidence and that he took the ones that support his belief, e.g., Mark saw Andrea touching her hair when she saw him some days ago. Sometimes, the agent may create his own evidence to justify his belief.

The nonevidentialist philosopher may state that Mark develops his beliefs according to nonevidential reasons, like pragmatic emotional ones: Mark believes that Andrea loves him too because that makes him feel better and motivates him to carry on.

Some evidentialists may admit that there is something pragmatic or motivational that affects belief creation. That explains why Mark chooses weak and poor evidence rather than more reliable evidence, like the testimonies of good friends (trustworthiness evidence) and seeing Andrea meeting another guy (direct perceptual evidence). But what Mark finally chooses to create and maintain his belief is weak evidence. The evidentialist may also show the nonevidentialist other cases:

(The earning money case) Suppose that one knows that if one were to believe that David Cameron's doctor's uncle has 132,487 hairs on his head one would receive a generous amount of money ... since the fact that one would receive a financial reward were one to have the relevant belief is no evidence that the belief is true, it seems that one cannot take it to justify so believing. ${ }^{8}$

${ }^{6}$ See David Papineau, "There Are No Norms of Belief," in The Aim of Belief, 64-79.

${ }^{7}$ Engel, "In Defense of Normativism About the Aim of Belief," 52.

${ }^{8}$ Whiting, "Reasons for Belief, Reasons for Action, the Aim of Belief, and the Aim of Action," 220.

(c) 2018 Marco A. Joven-Romero

https://www.kritike.org/journal/issue 22/joven-romero june2018.pdf

ISSN 1908-7330

(cc) BY-NC-ND 
The agent cannot believe at will. Belief is said to be transparent, automatic, and involuntary. ${ }^{9}$ Psychological facts do not allow to create the beliefs we want to have, but they adjust to evidence. However, the nonevidentialist may also reply with other cases:

(The lottery case) Jimmy decides to play the lottery. The probability of winning the lottery is $0.01 \%$, but he believes that today he is going to win the lottery. Intuition or something like that tells him that. He believes he is going to win the lottery today.

The nonevidentialist shows that the evidence of winning the lottery is very small, as small as its probability. Nevertheless, Jimmy really takes to be true that he is going to win the lottery. This case is quite similar to Mark's love case. The evidentialist may reply that, even if the probability is small, it exists. The problem would arise if Jimmy plays the lottery without any opportunity to win, that is, buying a number that is not inside the lottery machine. In that case, there is no evidence.

It should be noted that Jimmy may assume that the probability of winning the lottery is very small. He plays because he just 'wants to try.' But this is not our case: Jimmy is convinced that today is his special day for winning the lottery. If Jimmy just wants to try, his commitment to truth is very low and his state is rather a guess ${ }^{10}$ or the belief that he has a probability of $0.01 \%$ of winning the lottery.

For the purposes of this paper, I do not need to defend an evidentialist or a nonevidentialist position. What I want to show is that belief is normative no matter if we have reliable, weak, or no evidence. In other terms, even if we assume nonevidential motivational reasons to believe, beliefs are normative. Nevertheless, I shall note that a middle point about evidence-considering it in a broad sense, admitting its existence in order to maintain beliefs, and admitting that in its choice influences nonevidential terms like pragmatic or motivational ones-may solve many of the problems and cases introduced in the debate. Perhaps, a deflated notion of evidence and the acceptance of conative features when selecting evidence are the clues. However, I want to show here that belief is normative independently of its reasons. The constitutive normativity relies on the believer involuntarily considering his belief to be true, and not on the correspondence of belief with

109.

${ }_{9}$ See Nicholas Unwin, Aiming at Truth (Basingstoke, UK: Palgrave MacMillan, 2007),

${ }^{10}$ See David John Owens, "Does Belief Have an Aim?" in Philosophical Studies, 115 (2003), 283-305 and Gibbons, "Knowledge versus Truth."

(C) 2018 Marco A. Joven-Romero

https://www.kritike.org/journal/issue 22/joven-romero june2018.pdf

ISSN 1908-7330

(c) BY-NC-ND 
the external reality. Even if we assume pragmatic nonevidential reasons to believe, beliefs are normative in this sense.

\section{The Aims of Belief}

Many philosophers consider that the aim of belief is truth, ${ }^{11}$ following Williams's maxim. ${ }^{12}$ Some of them interpret this aim in a normative way: there is a norm of belief that tells that a correct belief is a true belief. These philosophers are usually called doxastic absolutists and they reformulate the norm in ways that accommodate this normative nature of belief and the attitude of the believer. ${ }^{13}$ Another interpretation of this aim is the teleological one, in which the cognitive system presents a goal of truth when believing is motivated by biological, psychological, and evolutionary facts, education, and training. ${ }^{14}$ Normative and teleological epistemologists accept truth as an aim of belief. But normativists consider a norm of truth while believing and teleologists consider different values apart from truth or deflate truth in terms of moral, personal, or aesthetic underlying values. ${ }^{15}$ Teleologists' commitment to truth is more lenient.

Taking the previous cases, Hugo considers that he sees a pig when he forms the belief that he sees a pig. It is clear that Hugo's belief aims at truth. Similarly, Tom is automatically considering that he gets the truth when forming the belief that the Earth is not the center of the universe. The difference between Hugo and Tom is that the former takes his direct sensory perception, whereas the latter takes the expertise and authority of his teacher as evidence. Maybe Hugo is mistaken by his senses and what he sees is not a pig but a dog. However, delusions are not problematic for a constitutive normativity based on the believer's attitude: although delusions are false beliefs, the believer considers them to be true; he simply fails in his performance. Similarly, Tom's teacher can teach something false, but it is not a problem: Tom considers his belief to be true. Mark also considers his belief that Andrea loves him to be true and Jimmy also considers his belief of

\footnotetext{
11 See José Zalabardo, “Introducción / Introduction," in Teorema: Revista Internacional de Filosofía, 32:3 (2013), 5-11, 13-18 and Timothy Chan, ed., The Aim of Belief.

${ }^{12}$ See Bertrand Williams, Problems of the Self (Cambridge: Cambridge University Press, 1973).

${ }^{13}$ One option is for an agent $S$ and a belief $p, S$ should believe $p$ if and only if $p$ is true." Interestingly, Whiting proposes a falsationist view of this normativity: " $S$ may believe $p$ if and only if $p$ is true. See Whiting, "Should I Believe the Truth?" A stronger epistemic commitment is adopted by the norm of knowledge proposed by Engel, Williamson, and Gibbons.

${ }^{14}$ See Asbjørn Steglich-Petersen, "How to Be a Teleologist about Epistemic Reasons," in Reasons for Belief, ed. by Andrew Reisner and Asbjørn Steglich-Petersen (Cambridge and New York: Cambridge University Press, 2011), 13-33.

${ }_{15}$ Papineau, "There Are No Norms of Belief."
}

(C) 2018 Marco A. Joven-Romero https://www.kritike.org/journal/issue 22/joven-romero june2018.pdf ISSN 1908-7330 
winning the lottery today to be true, but these cases are different: we know that the former is false, while the latter is highly unlikely. Moreover, both Mark and Jimmy have enough evidence of the falsity or the unlikeliness of their beliefs being true, but it does not break the constitutive relationship between belief and truth that I defend.

Traditionally, philosophers have related doxastic positions with evidentialism. ${ }^{16}$ Beliefs aim at truth because they are created according to evidence. Hugo believes that he truly sees a pig because he has evidence. Tom considers that his belief about the Earth not being the center of the universe is true because he takes the trustworthiness on his teacher as evidence. Even in the love and lottery cases, doxastic philosophers may assume that Mark and Jimmy consider their beliefs to be true because they take some evidence, no matter if the evidence is false or poor and so their beliefs incorrect. ${ }^{17}$ In other words, false beliefs do not pose any problem for the doxastic position of belief: they are just mistakes - in the same way that an expert teacher can be mistaken and teach an incorrect issue, or in the same way that being in a desert may create delusional beliefs on agents. In the earning money case, as the agent has no evidence, he cannot create a belief; whereas, in the case of the lottery, similarly to Mark's love, Jimmy's belief aiming at the 'extremely unlikely truth' that he is going to win the lottery might be explained in terms of the poor evidence of having a very small probability of winning it-as small as you want but the chance is always there.

Another possible approach to the aim of belief is the pragmatic one: belief aims at pragmatic considerations or belief aims at justification, in pragmatical terms. ${ }^{18}$ It is not a common view among epistemologists; sometimes, it is openly criticized but it deserves some explanation in order to use it in the following sections. From that point of view, there is no doxastic absolutism and constitutive norms about belief, and the only internal motivational requirement would be that of fitting the world and getting practical outcomes. Hugo believes he sees a pig to manage the environment and get some profit, i.e., perhaps he is hungry and seeing that pig allows him to hunt it. Similarly, Tom believes what his teacher tells him because it is useful, i.e., such information is likely to be useful to pass the test and thus get

16 See the following: Alan Millar, "Reasons for Belief, Perception, and Reflective Knowledge," in The Aristotelian Society Supplementary Volume, 88:1 (2014), 1-19; J. David Velleman, The Possibility of Practical Reasoning (Oxford: Oxford University Press, 2000); Nishi Shah, "How Truth Governs Belief," in The Philosophical Review, 112:4 (2003), 447-82; and Asjbørn SteglichPetersen, “Does Doxastic Transparency Support Evidentialism?" in Dialectica, 62:4 (2008), 541-7. 17 See Owens, "Does Belief Have an Aim?"

18 See the following: Richard Rorty, Truth and Progress, vol. 3 of Philosophical Papers (Cambridge: Cambridge University Press, 1998); Richard Rorty, "Universality and Truth," in Rorty and His Critics, ed. by Robert B. Brandom (Malden: Blackwell Publishers, Inc., 2000), 1-30; and Richard Rorty, "Response to Donald Davidson," in Rorty and His Critics, 74-80.

(C) 2018 Marco A. Joven-Romero

https://www.kritike.org/journal/issue 22/joven-romero june2018.pdf

ISSN 1908-7330

(cc) BY-NC-ND 
a better job in the future. This approach can explain Mark's love for Andrea in a more intuitive manner: Mark develops his belief that Andrea also loves him to feel better and keep on; his belief has practical and motivational reasons and consequences. In the lottery case, Jimmy's belief that he is going to win the lottery is not useful, as he has very little chance of winning. The pragmatist might argue that Jimmy's belief allows him to feel better during the day. Nevertheless, this pragmatic approach hardly explains the earning money case: the most useful practical outcome is to believe that David Cameron's uncle has 132,487 hairs in his head, but we cannot believe it at will as we have no evidence for its truth. The pragmatist may offer possible scenarios in which not believing that David Cameron's uncle has 132,487 hairs in his head is something useful. But there are other cases in which agents believe the truth, and such truth hardly seems to be useful. Opposite to wishful thinking cases like Mark's love for Andrea and Jimmy's lottery, there are beliefs in which epistemic analyses are more accurate than pragmatic ones:

(Kate's hated terrorist son case) Kate is terminally ill. Her son is a terrorist hated by the whole, or almost the whole, country and she believes so because there is enough reliable evidence showing that her son is a terrorist.

In this case, to believe the truth is not practical. For Kate, the most practical thing is to believe that her son is innocent, but she does not as she has evidence to believe he is guilty. It is difficult to envisage situations in which believing the truth is useful for Kate. Or at least, it is a very plausible option to consider that it is more practical for Kate to believe that her son is innocent better than to consider that her son is guilty.

Traditionally, pragmatism is related to nonevidentialism in a broad sense: we may take evidence as the reason for belief if it is practical, but we can also have other practical nonevidential reasons for belief. ${ }^{19}$ Hugo's pig and Tom's teacher cases are among the former, while Mark's love and Jimmy's lottery cases are among the latter. In other words, when the evidence forms useful beliefs, pragmatic accounts coincide with straight epistemic accounts. When nonevidential reasons (like motivational ones) contribute to the formation of beliefs, pragmatism offers a plausible approach for these beliefs (like in wishful thinking). But pragmatism can hardly manage cases where there is no evidence to believe the practical (as in the earning money case) or where beliefs are not practical (as in Kate's hated terrorist son case).

${ }^{19}$ See Rinard, "Against the New Evidentialists."

(c) 2018 Marco A. Joven-Romero https://www.kritike.org/journal/issue 22/joven-romero june2018.pdf ISSN 1908-7330 
Evidentialists may state that in Mark's love case, Mark takes evidence to form belief, and in that way, his belief aims at truth. The only problem is that he takes poor or weak evidence. In that case, they have to give a chance to the nonevidentialist, by admitting that pragmatic motivational reasonsor broadly put, non-evidential conative reasons-influence the way Mark chooses the evidence.

It can be said that, in the long run, the most practical thing is to get the truth, ${ }^{20}$ and so take only reliable evidence and no other nonevidential reasons. So, even if Mark is happier considering that Andrea loves him, in the long run, he will be better if he knows the reality as soon as possible: in that way, truth will hurt Mark less and he can start thinking about other things. However, that is not the way beliefs work: Mark is convinced of the requited love no matter if it is more or less practical in the short run or in the long run. If we assume that the most practical thing in the long run is truth, then there are beliefs that are neither true nor practical. These beliefs can be negatively evaluated, so there can be evaluative norms on beliefs in terms of different standards of correctness. For instance, from an epistemic standard of correctness, a belief is correct if and only if it is true. From a more pragmatic standard of correctness, a belief is correct if and only if it is useful. Mark's love case is incorrect from an epistemic standard of correctness, and it can be positively evaluated in the short run from a pragmatic standard of correctness and negatively evaluated in the long run from the same pragmatic standard of correctness. But the constitutive norm of belief I am considering does not relate to the outcomes or their correctness, but to the very attitude of the believer while believing: the believer of $p$ takes $p$ to be true. In that way, I establish a constitutive link between belief and truth no matter how the belief is formed, no matter how nonevidential reasons may influence belief formation, and no matter if the belief turns out to be either true or false.

\section{An Evidential Approach to Belief That Aims at Practical Reasoning for Actions}

Recently, some philosophers ${ }^{21}$ are exploring a new direction: to consider that beliefs aim at truth, truth provides practical reasoning for further action, and as a result, agents take evidence to create those beliefs. Far from assuming the traditional dichotomy between epistemic and practical perspectives, they try to include the former into the latter. Among these

\footnotetext{
${ }^{20}$ See Susan Haack, "Concern for Truth: What It Means, Why It Matters," in Annals of the New York Academy of Sciences, 775:1 (June 1995), 57-63 and Unwin, Aiming at Truth, 147.

${ }^{21}$ See David John Owens, "Value and Epistemic Normativity," in Teorema: Revista Internacional de Filosofía, 32:3 (2013), 35-58.

(C) 2018 Marco A. Joven-Romero

https://www.kritike.org/journal/issue 22/joven-romero june2018.pdf

ISSN 1908-7330

(cc) BY-NC-ND
} 
philosophers, Whiting 22 has recently offered an accurate approach: he considers that evidence is the only reason to create beliefs because beliefs aim at truth and in that way such beliefs aim at practical reasoning for subsequent actions. When forming beliefs, agents aim at truth, truth constitutes practical reasoning for action, and as a result they choose only evidence that ensures they can get these practical considerations. In Whiting's words:

A subject takes something to be a reason for believing that $p$ only if it provides evidence that $p$, because only evidence that $p$ indicates that, were she to believe that $p$, she would satisfy her aim to believe that $p$ only if that $p$ is a practical reason.

In effect, I am suggesting that the aim of believing only what is a practical reason generates or incorporates a more familiar aim which is satisfied only if one's belief is true, that is, only if what one believes is a fact.

... appealing to the independently motivated suggestion that subjects aim to believe only what is a practical reason explains why they aim to believe only the truthsubjects have the former aim because they have the latter aim. ${ }^{23}$

In the background, we have the idea that truth is practical: "a subject cannot have a particular practical aim which conflicts with and overrides the aim to believe only the truth." ${ }^{24}$ We can resume Whiting's position in three main ideas about beliefs:

(i) Beliefs aim at truth.

(ii) Truth constitutes practical reasoning for further actions.

(iii) A commitment to evidentialism.

The result of making a difference between belief and actions, and the result of conjugating both practical considerations for actions and evidentialism for beliefs, are what allow the agents to accommodate some

${ }^{22}$ See the following: Whiting, "Reasons for Belief, Reasons for Action, the Aim of Belief, and the Aim of Action."; Daniel Whiting, "Truth: The Aim and Norm of Belief," in Teorema: Revista Internacional de Filosofía, 32:3 (2013), 121-135; and Daniel Whiting, "Nothing but the Truth: On the Norms and Aims of Belief," in The Aim of Belief, 184-203.

${ }^{23}$ Whiting, "Reasons for Belief, Reasons for Action, the Aim of Belief, and the Aim of Action," 225-6.

24 Ibid., 227.

(C) 2018 Marco A. Joven-Romero

https://www.kritike.org/journal/issue 22/joven-romero june2018.pdf

ISSN 1908-7330 


\section{DO WE NEED REASONS FOR THE NORMATIVITY OF BELIEF?}

kind of pragmatism with doxastic normativism. Nevertheless, some of our examples pose some problems to these principles.

In Hugo's pig case, it is possible to state that Hugo's belief that he sees a pig is a practical reason to act-i.e., as I said before, perhaps he is hungry and seeing the pig allows him to hunt it-and its usefulness is motivated by perceptual evidence. Similarly, in Tom's teacher case, Tom's belief about the Earth not being the center of the universe is practical in order to pass the test and get a better job in the future, and such belief is based on the evidence given by the authority and expertise of his teacher. In these cases, both (i) and (ii) are accomplished.

In Mark's love case, we may also state that belief aims at practical reasoning: the false belief is useful in order to feel better and carry on. Nevertheless, as already stated, we can have both evidentialist and nonevidentialist analyses of the case: if we accept the former, then we assume that Mark takes some weak or poor evidence to create and maintain his belief, he considers his belief to be true and as a result his belief provides him with practical reasoning to act. That is feasible for Whiting. If we assume the latter, then Whiting's approach is not feasible ( $\neg$ iii). Whiting assumes evidentialism from the beginning, stating that "[I]f evidentialism is the thesis that only evidence provides reason for believing, then subjects are committed to evidentialism." 25

In the earning money case, what is practical for the agents is to create false beliefs in order to earn a lot of money. But as agents do not have the proper evidence ( $\neg$ iii), they cannot do it ( $\neg$ i). Evidence and practical outcomes are at odds, and no belief is developed. For Whiting, in order to analyze the earning money case, we need first to assume that evidence is mandatory to develop beliefs and that this lack of evidence is not practical, as it does not allow us to develop the practical belief. Whiting argues that the aim of belief is to provide reasons from evidences for acting and reasoning. ${ }^{26}$ In cases like the earning money case, agents cannot develop these beliefs because they do not have the evidence.

In the lottery case, what is practical for Jimmy is not to play the lottery. Nevertheless, similar to Mark's love case, one might say that it is useful for Jimmy to believe he is going to win the lottery to face the day ahead (i, ii). If we accept an evidentialist approach, we might say that there is little evidence - as little as the probability of winning the lottery - but it still exists (iii). If we do not accept it, Whiting's approach is not possible, as belief aims at the practical because there are evidential reasons for it.

${ }^{25}$ Ibid., 219.

${ }^{26}$ See ibid.

(C) 2018 Marco A. Joven-Romero

https://www.kritike.org/journal/issue 22/joven-romero june2018.pdf

ISSN 1908-7330

(cc) BY-NC-ND 
In the case of Kate's hated terrorist son, what is practical for Kate is to believe that her son is innocent, but she does not. It is difficult to envisage situations in which knowing the truth is more useful than knowing the falsity, as Kate is terminally ill and she is likely to be happier believing that her son is innocent. Here, belief aims at truth, but it is difficult to consider that truth to be practical reasoning for action ( $\neg \mathrm{ii})$, and all this is based on reliable evidence (iii). As I said, some philosophers may argue ${ }^{27}$ that in the long run the most practical option is the doxastic one, but in this case, Kate has no 'long run.' Whiting takes it difficult to think about beliefs on which agents will not act on or reason in any way from. ${ }^{28}$ All beliefs provide practical reasoning for further action or thought. In other words, truths given by beliefs always work as practical reasons for actions or thoughts, even if it is difficult to envisage how a particular belief can provide practical reasoning for action or thought, like in the case of Kate's hated terrorist son. For these cases, Whiting considers a holism about beliefs: even if a given belief seems to provide no reason to act or think, this belief stands in systematic links with other beliefs. In other words, an apparent useless or bad belief influences many other beliefs. A belief that a subject knows presents no potential practical or theoretical significance for latter action would be the exception, not the rule.

In short, in order to apply Whiting's ideas to different belief cases, we need to assume: (a) evidence is necessary to form beliefs, (b) beliefs aim at truth based on evidence and not directly at practical issues, and (c) truth always constitutes practical reasoning to act but it is not the only practical reasoning to act. It can be thought that in some cases these conditions are too demanding. We need to assume the existence of evidence to form beliefs in cases in which nonevidentialist approaches seem to be good approaches, e.g., Mark's love case and Jimmy's lottery case. Moreover, we need to assume that belief aims at truth, truth being a practical consideration based on evidence in some cases in which it seems more plausible to think that belief aims at true nonpractical considerations based on evidence, e.g., Kate's hated terrorist son case. In other words, Whiting's approach implies that (1) evidence is necessary to form beliefs and (2) truth constitutes practical reasoning for subsequent action. It denies nonevidential reasons to form beliefs: it denies possible beliefs based on nonevidential reasons that aim at practical outcomes and that truths may not constitute practical reasoning for further action or thinking.

Whiting in some way realizes these criticisms:

\footnotetext{
${ }^{27}$ See Haack, "Concern for Truth: What It Means, Why It Matters." See also Unwin, Aiming at Truth, 147.

${ }^{28}$ See Whiting, "Reasons for Belief, Reasons for Action, the Aim of Belief, and the Aim of Action."
}

(c) 2018 Marco A. Joven-Romero https://www.kritike.org/journal/issue 22/joven-romero june2018.pdf ISSN 1908-7330 
I have accounted for the fact that a subject cannot take practical considerations to justify or favor having a certain belief on the basis of which she will act or decide, since to do so might be to thwart her aim to act only on practical reasons. But suppose that a subject knows that, if she were to believe some utterly trivial proposition which will never figure in her practical reasoning, she would receive a large reward ... Why, then, can't she take the fact of the reward to justify so believing? ....

If the relevant subject is to take the practical consideration to justify believing the trivial proposition, she must take the belief to be, not only one which she will not act on, but one which she will not reason in any way from. It is not clear what kind of belief would pass this test. ${ }^{29}$

Whiting answers to possible critics considering that beliefs formed on nonevidential reasons are beliefs that agents cannot use to act or to reason, so they cannot be practical reasons for action. He argues that the aim of belief is to provide reasons from evidences for further acting and reasoning. In cases like the earning money case, the truth given by the belief is different from the apparent practical reasoning for action based on no evidence: agents cannot develop these beliefs because they do not have the proper evidence. So, truth constitutes practical reasoning for action, but it is not the only practical reasoning actions may have. Agents may act in terms of their desires. And beliefs aim at truth as they are based on evidence. In short, Whiting's way of accommodating pragmatic and epistemic perspectives relies on making a difference between beliefs as states and actions, on considering truth as practical reasoning for actions, and on a commitment to evidentialism. Let's recall Mark's case:

(Mark's love case) Mark is in love with Andrea and he is convinced that it is a requited love. Andrea does not love Mark, and she tells him so. Furthermore, Mark's friends try to convince him showing opposite evidence and Mark has himself seen Andrea dating another boy many times. But it does not matter: for Mark, Andrea is just playing hardball with him. Mark believes Andrea loves him too.

${ }^{29}$ Ibid., 232-3.

(C) 2018 Marco A. Joven-Romero

https://www.kritike.org/journal/issue 22/joven-romero june2018.pdf

ISSN 1908-7330

(c) BY-NC-ND 
According to Whiting's ideas, Mark needs some evidence to develop his belief that Andrea loves him too. This belief is false, but Mark takes it to be true because of some evidence. This, then, provides a practical reason that guides his action or thought. The evidence is likely to be poor. For instance, maybe Mark saw Andrea touching her hair the last time she saw him. But the evidence exists. On the contrary, a nonevidentialist philosopher would say that Mark does not need any evidence to develop his belief.

Another possible reply is that Mark's state is not a belief but a desire. He desires that Andrea loves him too, but as he has no evidence, the requited love is a desire and not a belief. There is no requited love, but just a desire to have this. This desire can also constitute practical reasoning to act. Nevertheless, the state of Mark is not only a desire, but also a belief: a false belief, but a belief, and to some extent it is also a useful belief.

I consider that there is a constitutive link between belief and truth that is independent of the evidence the believer may have: believers take their beliefs to be true, regardless of the good, bad, or nonexistent evidence they may have. This option covers the possible cases and alternatives. Only a belief whose believer considers to be false would be a counterexample, but it is not clear which belief would pass this test.

As I see it, reasons for belief sometimes may be epistemic (e.g., Hugo's and Tom's cases) and other times may be nonepistemic ${ }^{30}$ (e.g., Mark's and Jimmy's cases). We can also find cases in which epistemic reasons are not powerful enough to develop beliefs (e.g., Mark's love and Jimmy's lottery cases) and also examples in which nonepistemic reasons are not powerful enough to develop beliefs (e.g., the earning money and Kate's hated terrorist son cases). Whiting relates practical reasons with epistemic reasons, but the practical may be epistemic or nonepistemic depending on the specific case.

In other words, we can have both cognitive and conative reasons for belief: in some beliefs, the cognitive reasons are more powerful than the conative reasons, while in others the conative reasons are more powerful than the cognitive ones. The definition of the "practical" can be both cognitive or conative, but it depends on the specific case. ${ }^{31}$ Moreover, beliefs may not be practical even if they are based on accurate evidences, such as in the case of Kate's hated terrorist son.

30 When I speak of nonepistemic reasons, I refer to reasons in which there can be evidential incomes, but they are not the main ones. In other words, the nonepistemic reasons may or may not include evidential reasons, but if there are evidential reasons to believe, they are outweighed by other nonevidential reasons.

31 See Rinard, "Against the New Evidentialists."

(c) 2018 Marco A. Joven-Romero https://www.kritike.org/journal/issue 22/joven-romero june2018.pdf ISSN 1908-7330 
In the next section I defend a constitutive normativity of belief without needing a commitment to evidentialism: believers consider their beliefs to be true.

\section{Nonreasons for Belief Aiming at Truth}

So far, I have sketched the evidentialist and nonevidentialist accounts. I have briefly related them to the doxastic and pragmatic approaches to the aim of belief. Finally, I have analyzed the account proposed by Daniel Whiting.

This approach is based on two main principles: evidentialism and belief aiming at practical considerations. The author tries to accommodate practical outcomes and reasons, to epistemic outcomes and reasons. Nevertheless, I have showed some possible counterparts:

(i) Evidence is not always practical. Sometimes, the motivational seems to be more practical.

(ii) Some beliefs are not formed on evidence. Or at least, these beliefs are not based on the best reliable available evidence. Other nonevidential considerations come into play.

I defend that belief is normative, but in another way:

(a) Believers consider their beliefs to be true.

(b) Reasons to believe do not matter for (a).

The believer has an involuntary commitment ${ }^{32}$ to truth: she always considers that her beliefs are true. For that reason, I do not need to assume an evidentialist nor a nonevidentialist position to defend a constitutive relationship between belief and truth. I do not need to care about the necessity or the reliability of the evidence. If we assume that there is no evidence for belief emergence, belief still aims at truth in the sense that, once the believer has her belief-no matter how it is formed-the believer is mirroring her reality - no matter if such reflection is correct or incorrect.

Agents may present 'different truths.' So, one agent may believe $p$ and another agent may believe $\neg p$ : although their beliefs about the same fact are different, both are epistemically committed to truth. Different agents may have 'different truths,' and we may defend an external knowledge as the goal of belief, but the relationship between knowledge and truth is beyond the

32 See Gibbons, “Knowledge versus Truth.”

(C) 2018 Marco A. Joven-Romero

https://www.kritike.org/journal/issue 22/joven-romero june2018.pdf

ISSN 1908-7330

(c) BY-NC-ND 
scope of this paper. ${ }^{33}$ Every agent aims at her truth when believing. The goal of these truths may be a trustworthy established knowledge, and in this process, reliable evidence and subjective honesty are likely to be necessary, but I just want to show that when believing - no matter 'how good or bad' the believer presents a commitment to truth. The constitutive normativity of belief relies in the believer involuntarily aiming at truth.

Hugo believes he sees a pig, so he considers that he truly sees a pig. Moreover, we may consider that he has good perceptual evidence for believing so. Perhaps his senses fail, he can be under the effects of hallucinogenic drugs, and what he sees is not a pig. But even under delusions, Hugo considers that what he sees is truly a pig.

Similarly, Tom believes that the Earth is not the center of the universe, so he considers that it is true that the Earth is not the center of the universe. Furthermore, we may consider that his teacher's testimony is good evidence for such belief. But his professor might be mistaken. Actually, for hundreds of years before, the most intelligent men believed that the Earth was the center of the universe. ${ }^{34}$ But it does not matter for our purposes, because Tom is under our constitutive norm: when believing that the Earth is the center of the universe, he considers that it is true that the Earth is the center of the universe.

Mark believes his love for Andrea is requited, so he considers the requited love to be true. We know it is false. The evidence actually shows he is mistaken: his friends know that, and they even try to convince him. Moreover, he himself has seen Andrea dating another guy. But it does not matter: Mark considers true that Andrea loves him too. As I said, in these wishful thinking examples, we may consider weak or poor evidence for believing (e.g., Andrea touched her hair the last time she saw Mark) or we may consider no evidence at all. It does not make any difference for our purposes: Mark believes his love is requited and when doing so, he takes it to be true that his love is requited. His belief aims at truth. His truth and his friends' truth are different. But the constitutive normativity of belief I defend relies on the agent considering truth that he believes and not on the final result and the external judgment of beliefs - even if getting this knowledge is commonly desirable.

In the earning money case, agents do not believe that David Cameron's doctor's uncle has 132,487 hairs on his head, because they simply do not consider that to be true. Evidentialists may also offer a reason: the

\footnotetext{
${ }^{33}$ See the following: Pascal Engel, "Truth and the Aim of Belief," in Laws and Models in Science, ed. by Donald Gillies (London: King's College Press, 2004), 77-97; Williamson, Knowledge and its Limits; and Gibbons, "Knowledge versus Truth."

${ }^{34}$ See Thomas Kuhn, The Structure of Scientific Revolutions (Chicago: University of Chicago Press, 2012).
}

(C) 2018 Marco A. Joven-Romero https://www.kritike.org/journal/issue 22/joven-romero june2018.pdf ISSN 1908-7330 
agents do not have enough evidence, and as a result, they cannot develop the belief. In terms of the constitutive norm I defend, the agents are epistemically committed, and as they cannot consider true that David Cameron's doctor's uncle has 132,487 hairs on his head, they cannot believe so.

Jimmy believes he is going to win the lottery. In doing so, he considers true that he is going to win the lottery, even if he has poor, or no evidence at all. This case is quite similar to Mark's love case and it implies an explicit belief of winning the lottery. Jimmy could also play the lottery 'just to try,' knowing that he has a probability of $0.01 \%$ of winning the lottery but not minding it. This is not our belief: this latter case is just a guess ${ }^{35}$ or the belief that he has a probability of $0.01 \%$ of winning the lottery.

Kate believes her son is a hated terrorist, and when doing so, she considers true that her son is a hated terrorist. For our purposes, this case is very similar to Hugo's and Tom's case: Kate just takes reliable evidence and she forms her belief, even when she would like to believe that her son is innocent. Here the nonevidential reasons for belief do not come into play but all this does not make any difference for my position: Kate just believes that her son is a hated terrorist, so she considers such thing to be true.

So, reasons for belief are independent of the constitutive norm of belief I propose: once a person has a belief about something, she takes it to be true. This is not in tension with the possibility of degrees of believing. So, the epistemic commitment ${ }^{36}$ of Hugo while seeing the pig may be stronger than the epistemic commitment of Tom when listening to his teacher. And the epistemic commitment of the latter may be stronger than the epistemic commitment of Kate when thinking about her son, and this may be stronger than the epistemic commitment of Jimmy playing the lottery. But all these beliefs, as well as Mark and John's beliefs, aim at the truth, in the sense that the believers take their beliefs to be true. And, most important, we do not need to assume any specific kind of reason for belief in order to defend this constitutive normative account of belief. Even if we need reasons in order to evaluate beliefs and to consider knowledge, the constitutive norm of belief relies in the agent's considerations during the act of believing regardless of the reasons and the results.

\section{Conclusions}

I have analyzed different ways of relating the nature of belief and its reasons and I finally defend a doxastic constitutive normativity of belief

\footnotetext{
35 See Owens, "Does Belief Have an Aim?"

${ }^{36}$ See Gibbons, "Knowledge versus Truth."
}

(C) 2018 Marco A. Joven-Romero

https://www.kritike.org/journal/issue 22/joven-romero june2018.pdf ISSN 1908-7330

(c) $)$ BY-NC-ND 
independent of its reasons: the believer considers true what she believes. For that, I treat different kinds of belief.

There are beliefs that aim at truth and that are motivated by evidential reasons. These beliefs may be practical. These are the cases of Hugo's pig and Tom's teacher.

Other beliefs are motivated by poor or no evidence. Nonepistemic reasons influence their formation. These are wishful thinking cases like Mark's love and the lottery case. These beliefs are false or likely to be false, as in the lottery case. They are hardly explained by evidentialist approaches. We have seen two of them: a traditional normative one that considers that beliefs aim at truth and are motivated by evidential reasons, and Whiting's ${ }^{37}$ approach (also normative) that considers that beliefs are motivated by evidential reasons, beliefs aim at truth, and truth constitutes a practical consideration for further action and thinking. If we give a chance to evidentialism, we need to assume the existence of poor evidence that is outweighed by nonevidential reasons.

A third kind of beliefs is motivated by reliable evidence. These beliefs aim at truth, but they are not practical, as in the case of Kate's hated terrorist son. These beliefs are hardly explained by approaches that relate belief and practical considerations. Such cases also pose a problem for Whiting's approach: they are based on evidence and they are not practical. The earning money case is also problematic for the 'belief aiming at practical considerations' approach: it is practical to develop a specific belief, but it is not possible without proper evidence.

After this analysis, I defend that all believers aim at truth when believing. It does not matter if their beliefs are caused by epistemic evidential or motivational nonevidential reasons, if they are practical or not. Once the agent believes something, she considers it to be true. The constitutive normativity of belief is set just on the act of aiming at truth done by the believer. The reasons and the results of beliefs are independent of this constitutive normativity that relates belief and truth: believers just aim at truth.

Ministry of Foreign Affairs and Cooperation-Agency for International Development Cooperation (MAEC-AECID), Spanish Government Department of Logic, History, and Philosophy of Science National University of Distance Education (UNED), Spain of Action."

${ }^{37}$ See Whiting, "Reasons for Belief, Reasons for Action, the Aim of Belief, and the Aim

(C) 2018 Marco A. Joven-Romero

https://www.kritike.org/journal/issue 22/joven-romero june2018.pdf

ISSN 1908-7330

(cc) BY-NC-ND 


\section{References}

Engel, Pascal, "Belief and the Right Kind of Reason," in Teorema: Revista Internacional de Filosofía, 32:3 (2013).

"In Defense of Normativism About the Aim of Belief," in The Aim of Belief, ed. by Timothy Chan (Oxford: Oxford University Press).

"Truth and the Aim of Belief," in Laws and Models in Science, ed. by Donald Gillies (London: King's College Press, 2004).

Gibbons, John, "Knowledge versus Truth," in Epistemic Norms: New Essays on Action, Belief, and Assertion, ed. by Clayton Littlejohn and John Turri (Oxford: Oxford University Press, 2014).

Haack, Susan, "Concern for Truth: What It Means, Why It Matters," in Annals of the New York Academy of Sciences, 775:1 (June 1995).

Kuhn, Thomas, The Structure of Scientific Revolutions (Chicago: University of Chicago Press, 2012).

Millar, Alan, "Reasons for Belief, Perception, and Reflective Knowledge," in The Aristotelian Society Supplementary Volume, 88:1 (2014).

Owens, David John, "Does Belief Have an Aim?" in Philosophical Studies, 115 (2003).

"Value and Epistemic Normativity," in Teorema: Revista Internacional de Filosofía, 32:3 (2013).

Papineau, David, "There Are No Norms of Belief," in The Aim of Belief, ed. by Timothy Chan (Oxford: Oxford University Press).

Rinard, Susanna, "Against the New Evidentialists," in Philosophical Issues, 25:1 (2015).

Rorty, Richard, "Response to Donald Davidson," in Rorty and His Critics, ed. by Robert B. Brandom (Malden: Blackwell Publihers, Inc., 2000).

Truth and Progress, vol. 3 of Philosophical Papers (Cambridge: Cambridge University Press, 1998).

"Universality and Truth," in Rorty and His Critics, ed. by Robert B. Brandom (Malden: Blackwell Publihers, Inc., 2000).

Shah, Nishi, How Truth Governs Belief," in The Philosophical Review, 112:4 (2003).

Steiglich-Petersen, Asbjørn, "Does Doxastic Transparency Support Evidentialism?" in Dialectica, 62:4 (2008).

"How to Be a Teleologist about Epistemic Reasons," in Reasons for Belief, ed. by Andrew Reisner and Asbjørn Steiglich-Petersen (Cambridge and New York: Cambridge University Press, 2011).

Unwin, Nicholas, Aiming at Truth (Basingstoke, UK: Palgrave MacMillan, 2007).

Velleman, J. David, The Possibility of Practical Reasoning (Oxford: Oxford University Press, 2000).

(C) 2018 Marco A. Joven-Romero

https://www.kritike.org/journal/issue 22/joven-romero june2018.pdf

ISSN 1908-7330

(c) $)$ BY-NC-ND 
Whiting, Daniel, "Nothing but the Truth: On the Norms and Aims of Belief," in The Aim of Belief, ed. by Timothy Chan (Oxford: Oxford University Press).

"Reasons for Belief, Reasons for Action, the Aim of Belief, and the Aim of Action," in Epistemic Norms: New Essays on Action, Belief, and Assertion, ed. by Clayton Littlejohn and John Turri (Oxford: Oxford University Press, 2014). "Should I Believe the Truth?" in Dialectica, 64:2 (2010), 213-224. "Truth: The Aim and Norm of Belief," in Teorema: Revista Internacional de Filosofía, 32:3 (2013).

Williams, Bertrand, Problems of the Self (Cambridge: Cambridge University Press, 1973).

Williamson, Timothy, Knowledge and its Limits (Oxford: Oxford University Press, 2000).

Zalabardo, José, "Introducción / Introduction," in Teorema: Revista Internacional de Filosofía, 32:3 (2013).

(c) 2018 Marco A. Joven-Romero https://www.kritike.org/journal/issue 22/joven-romero june2018.pdf 